\title{
Introducing Critical Librarianship to Information Professionals: Using Critical Pedagogy and Critical Information Literacy in an LIS Graduate Course
}

Marcia Rapchak

University of Pittsburgh, mrapchak@pitt.edu

Follow this and additional works at: https://pdxscholar.library.pdx.edu/comminfolit

Part of the Information Literacy Commons

Let us know how access to this document benefits you.

\section{Recommended Citation}

Rapchak, M. (2021). Introducing Critical Librarianship to Information Professionals: Using Critical Pedagogy and Critical Information Literacy in an LIS Graduate Course. Communications in Information Literacy, 15 (1), 140-157. https://doi.org/10.15760/comminfolit.2021.15.1.8 


\title{
Introducing Critical Librarianship to Information Professionals: Using Critical Pedagogy and Critical Information Literacy in an LIS Graduate Course
}

\author{
Marcia Rapchak, University of Pittsburgh
}

Abstract

Critical librarianship, which critiques the role of libraries and information professionals in maintaining systems of oppression, has been growing in popularity in the profession, and instructors in Library and Information Science (LIS) have begun to address critical librarianship in their coursework. While critical pedagogy and critical librarianship have influenced approaches to LIS education, the intersection of these two has not been as thoroughly addressed. Additionally, the literature on critical information literacy focuses largely on library instruction. This case study explores a critical pedagogy approach in a critical librarianship class that prepares students for critical information literacy instruction. The instructor implemented student-led presentations and discussions, self-grading, and collaboratively setting course expectations. Student responses were overwhelmingly positive, and student performance in the course indicated the approach and content of the course were effective.

Keywords: critical pedagogy, critical librarianship, critical information literacy, antiracist pedagogy

\section{Innovative Practices}

\section{edited by Andrea Baer, Carolyn Gamtso, and Merinda McLure}

Rapchak, M. (2021). Introducing critical librarianship to information professionals: Using critical pedagogy and critical information literacy in an LIS graduate course.

Communications in Information Literacy, 15(1), 140-157.

\footnotetext{
Copyright for articles published in Communications in Information Literacy is retained by the author(s). Author(s) also extend to Communications in Information Literacy the right to redistribute this article via other scholarly resources and bibliographic databases. This extension allows the authors' copyrighted content to be included in some databases that are distributed and maintained by for-profit companies. All other rights of redistribution are licensed by Communications in Information Literacy under Creative Commons Attribution-NonCommercial-ShareAlike 4.0 International (CC BY-NC-SA 4.0).
} 


\section{Introducing Critical Librarianship to Information Professionals: Using Critical Pedagogy and Critical Information Literacy in an LIS Graduate Course}

As someone teaching in a Library and Information Science (LIS) graduate program, I have the opportunity and obligation to prepare graduates to work with their communities to seek equity and justice. Given the continued harm against Black Americans, Asian American and Pacific Islanders, and marginalized peoples in the United States, it is essential that our students understand what is at stake for our various communities-racial justice, rights and humane treatment for immigrants and refugees, and better protections for LGBTQ+ folks are a few of the major issues for which our communities are fighting. Libraries, archives, museums, and other cultural heritage institutions cannot remain neutral in the face of widespread injustice. To do so tacitly supports systems of oppression. We must work with our students to find ways to make our institutions spaces for our communities to seek freedom.

One way to address issues of social justice in LIS programs is through teaching about critical librarianship and preparing students to take critical information literacy approaches in their own instruction. Critical librarianship, which encourages a critical view of libraries and librarianship as maintaining the status quo and oppression, has been growing in popularity in LIS and has been taught in several graduate LIS programs (Cooke et al., 2016; Mehra \& Rioux, 2016; Roberts \& Noble, 2016). This case study examines the use of a critical pedagogy approach to teaching a critical librarianship course and its impact on student learning related to critical information literacy. The course responds to call to action from Hackney et al. (2018): "LIS educators could also do more to incorporate readings and assignments that engage with identities into their syllabi, and highlight identity issues in their pedagogy as well" (p. 30) and models for students critical information literacy instruction that they could adapt for their current and future institutions.

I must recognize my positionality as a white woman in LIS, which means that while trying to take an antiracist critical pedagogy approach, I am indebted to Black scholars and other scholars of color who have explored social justice in LIS, critical race theory, and critical pedagogy. As Cooke, Sweeney, and Noble (2016) discussed, issues of social justice and 
racism in LIS coursework cannot fall only to BIPOC faculty and students. All of us must take up these issues, and critical librarianship in the curriculum allows us to look at structures of oppression from an intersectional lens and consider how we might prepare librarians to work with their communities to address them.

\section{Literature Review}

\section{Critical Librarianship}

Critical librarianship, informed by a variety of critical perspectives, provides a framework of critiquing traditional librarianship, along with the structures and systems surrounding libraries. It highlights the complicity of libraries and librarians in systems of oppression: cataloging systems that perpetuate racist, ableist, heterosexist, and cisnormative approaches to the world (Adler, 2017; Drabinksi, 2008); classist and racist systems of information access (Hare \& Evanson, 2018; Honma, 2005; Noble, 2018); and hiring structures that perpetuate white supremacy in librarianship (Galvan, 2015; Hathcock, 2015). It recognizes libraries are parts of intersecting systems of power that perpetuate policies, norms, and structures that keep some people from accessing, being represented by, and producing information. Librarians have historically not recognized the role they play in exercising power and perpetuating ideas about cultural capital, and only by critical reflection can they uncover their participation in shaping and privileging certain voices and not others (Budd, 2003). Along with being critical as in informed by critical theory and critiquing the status quo, critical librarianship is seen as critical in the sense that it is paramount for librarians to work for justice (McElroy, 2017). Critical librarianship recognizes the local context of individual libraries and the political, social, cultural, and economic contexts that extend beyond the library. The library does not exist in a vacuum; the critical nature of fighting on all fronts for a more just society means libraries and librarians must play a role in both dismantling the structures that harm communities and in advocating for their communities who have been harmed. One powerful way in which librarians can begin to work with their communities to confront these structures is through critical information literacy instruction.

\section{Critical Information Literacy}

Critical information literacy instruction is one method of applying the concepts of critical librarianship (Barr-Walker \& Sharifi, 2019). Critical information literacy addresses structures of power in the information environment, focusing specifically on the patron's 
understanding of the intersecting systems that shape information (Tewell, 2015). Critical information literacy instruction enables students and patrons to be active agents in seeking and using information for issues relevant to their lives. It emphasizes the role of students as not just consumers of such information but also participants who collaborate to create and share information for a purpose.

Critical information literacy moves beyond looking at information as a noun (Elmborg, 2012) to making instruction regarding information literacy relevant to the lives of our students through valuing and integrating their own ideas and experiences (Swanson, 2004). It encourages students to uncover and critique the social, political, and economic structures that shape the ways in which individuals access, value, create, and use information. Instead of purporting that information is neutral, critical information literacy recognizes the ways in which information is used to maintain the status quo and hegemony. This recognition of the role of information in systems of oppression can encourage those who engage in critical information literacy to work with their communities for social justice.

Critical Pedagogy

Teaching critical librarianship and critical information literacy lends itself to a critical pedagogy approach. Critical pedagogy similarly includes a critique of systems of oppression and power, including traditional education's maintenance of hegemony. Instead of the instructor bestowing knowledge on students as if students inherently lack knowledge, critical pedagogy uses problem-posing educational strategies to encourage students to critique their current circumstances and propose methods of overcoming challenges created by systems of oppression. The learning experience becomes one of dialogue and collective exploration. As Freire (1970/2009) explained:

Through dialogue, the teacher-of-the-students and the students-of-the-teacher cease to exist and a new term emerges: teacher-student with students-teachers. The teacher is no longer merely the-one-who-teaches, but one who is himself taught in dialogue with the students, who in turn while being taught also teach. (p. 169)

The students' own experiences and understanding of their world is shared and recognized as contributing to the collective knowledge creation process.

As a form of critical pedagogy, antiracist pedagogy allows us to confront systemic racism inside and outside of the classroom. Antiracism is more than being "not racist"; it is 
identifying racism and then acting in ways to counter policies and structures that perpetuate racist systems (Kendi, 2019). Antiracist pedagogy asks faculty members to recognize their own positionality and participation in white supremacy (Kishimoto, 2018). Faculty, especially white faculty, need to learn about and reflect on our role in racism; as Kishimoto (2018) said:

"Despite our advanced degrees, when discussing the impact of racism on certain communities, faculty need the humility to acknowledge that we can also learn from students and community members who may lack formal credentials but are keenly knowledgeable about how institutional racism operates. (p. 544)

This de-centering of authority is essential to critical pedagogy, where issues of authority, often addressed in information literacy, are considered in ways beyond credentialing, especially as it relates to experiencing racism.

Much of the literature about critical pedagogy in LIS is related to critical information literacy instruction or using critical pedagogy in library instruction. Pagowsky and McElroy's (2016) two-volume series Critical Library Pedagogy Handbook includes examples of how to integrate critical pedagogy and critical information literacy, both for librarians and LIS educators. These include opportunities for authentic learning, collaboration and group discussion, and centering of students in the classroom as issues of authority, source credibility, information representation and exclusion, and social justice and injustice are explored, with essays by Hochman (2016)and Forest and Kimmel (2016) focusing specifically on LIS education. Similarly, Tewell's (2018) survey of librarians found the practice of critical information literacy appeared in topics they covered (like alternative media, classification, and search examples) along with their teaching strategies (like discussion, group work, and problem-posing). Angela Pashia (2016) described an antiracist critical pedagogy approach in addressing issues of authority and reliability in coverage of the Black Lives Matter movement. Critical examination and critiquing of traditional information literacy topics and critical pedagogy techniques seem to be at the heart of critical information literacy.

There is some existing literature on a critical pedagogy for preparing future librarians. Nicole Cooke and Miriam Sweeney (2017) edited an essential resource for LIS educators titled Teaching for Justice: Implementing Social Justice in the LIS Classroom; many chapters discuss topics that could fall under the critical librarianship umbrella, though the term is not 
used in the book. The courses described in the book focus on critiques of systems of power and privilege, how they address oppression based on race, gender, sexuality, and other identities, and how social justice can become a focus of librarianship; much of these courses take a critical pedagogy approach. For example, Kurz (2017) related that her courses are highly participatory and require much student discussion that center students' experience. Hughes-Hassell and Vance (2017) described how they created a classroom environment that fostered conversation about difficult topics, like racism, white privilege, and stereotypes, through reflection, respect, and recognition that all in the class played the role of teacher and learner. Even if not explicitly named, critical pedagogy has influenced many LIS instructors as they prepare their students for their own instructional roles in libraries. This case study describes a critical pedagogy approach that flattens hierarchies in ways that some of the previous literature has not addressed.

\section{Critical Librarianship for Information Professionals Course}

\section{Course Introduction}

I wanted to go beyond what I had practiced as a critical pedagogy approach that, like much of the other LIS literature described, fostered student participation through discussion and assignments that encouraged reflection. I wanted to experiment (recognizing that white privilege lets me experiment without the concern BIPOC faculty face of retribution) with giving up power in ways I had not before in the classroom, to reflect on my own practice and assumptions as a professor, and to see what my students could accomplish when traditional expectations of the relationship between professor and student are (at least partially) dismantled. My intention was to move to antiracist critical pedagogy. As Kishimoto (2018) explained, "Anti-racist pedagogy focuses on the process of learning, not necessarily making students reach a uniform and prescribed outcome" (p. 546). The Critical Librarianship for Information Professionals course at the University of Pittsburgh seemed an opportunity where the process of learning could be emphasized.

The course was an elective offered for the first time in the summer of 2020 and had seventeen enrolled students, sixteen of which were in the MLIS program and one of which was in the Master's of Public Health program. I was inspired to design and offer this course after hearing from and reading the work of folks who have been asking LIS programs to better prepare students for social justice work for years (Honma, 2005; Mehra \& Rioux, 
2016; Roberts \& Noble, 2016). A single course does not represent the transformation of the program, which did have courses on diversity and community engagement. Still, students in the class were eager to engage in the content; we regularly ran out of time in our weekly three hours over Zoom. They were open to learning in what was a new fashion for many of us, contributing from day one with ideas about how to create a respectful course climate, including how to make sure all voices were heard (with the Zoom chat and hand-raising functions) and how to "call in" a participant who said something inappropriate or hurtful. Students were enrolled either in the synchronous (fourteen students) or asynchronous (three students) version of the course, which was entirely online because of COVID-19. Synchronous course sessions were recorded so asynchronous students could benefit from the content covered in these sessions. Each week focused on a different aspect of critical approaches to librarianship. The overall learning outcomes were:

- Define critical librarianship and the critical theories that contribute to our understanding of critical librarianship.

- Reflect on how library and information systems contribute to power imbalance and marginalization.

- Evaluate professional values (neutrality, freedom of information, freedom from censorship) in light of critical librarianship.

- Empower community members to use information resources for justice.

\section{Critical Pedagogy in the Course}

I enacted critical pedagogy and critical information literacy in the course in several ways: the students led each session, the course was heavily discussion-based, and the students graded themselves (a form of ungrading). I told students at our first session that they would run the course and the direction of our conversations. While I determined most of the readings, assignments, and the general structure of the course, students were largely in control of the direction of each class session and able to choose their own topics and modify each assignment. In this way, the course represented a critical information literacy approach by decentralizing authority and allowing students to share their own experiences and understanding as legitimate sources of knowledge. Student presentations and student-led discussions created a co-learning environment where everyone was responsible for contributing to the generation of new ideas and knowledge. Their experiences in libraries 
and elsewhere provided greater understanding of the concepts presented and how they applied to real-world situations. I took on a co-learning role, sometimes presenting content or discussion questions but more often acting as a participant while students presented and discussed. This resisted the traditional hierarchy that presents the teacher as more knowledgeable than students, allowing for a variety of experiences in libraries and elsewhere to be explored. This is not only fitting for a critical librarianship course but also for any course in LIS or sessions taught by academic librarians, especially given the range of experiences and backgrounds of our students.

I was transparent from the beginning with what I was trying to accomplish in the course and why I was taking the approach I was, addressing critical pedagogy explicitly, to encourage student buy-in. Students felt they had ownership of the course because of the shared decision-making environment. Had there been resistance to this, I would have spent more time elucidating what I was trying to accomplish. Because of the wide variety of topics, for students who were less comfortable with the more "radical" ideas of the course, they could lead sessions more aligned with their interests. Additionally, since students were leading the conversations, we explored difficult topics together rather than from a didactic approach.

Before the course started, students signed up for the class session they wished to lead and then were asked to identify and read at least two additional articles or book chapters on the topic. Topics ranged from Critical Race Theory to disability studies to queer theory, along with an examination of how these theories intersected with librarianship. Students gave a presentation on the topic, generated discussion questions to present to the class, and moderated the class discussion. For the synchronous students, this required responding to student ideas and questions in real-time. For the asynchronous students, this meant responding to students in the discussion board, often with prompting questions encouraging further exploration of ideas and making connections with the ideas of other students. This allowed students to practice critical pedagogy strategies they could implement in their own careers in libraries, museums, and archives. The discussion questions students generated were often problem-posing questions focusing on praxis within their current or future roles in libraries; for example, questions from an MLIS student who currently works in the public library asked, "Where in LIS do you recognize white power structures firmly in place? How could you approach questioning or dismantling these power structures?” The

[INNOVATIVE PRACTICES ]
Rapchak

Introducing Critical Librarianship to Information Professionals 
problem-posing approach allows those teaching critical information literacy to address collaboratively an issue relevant to the class and critique traditional structures of information dissemination and access (Tewell, 2018).

The course was responsive to the context of national conversations. After the deaths of George Floyd, Breonna Taylor, and Tony McDade, among others, students shared their concerns about policing and violence against Black lives throughout the class sessions. While policing in libraries was not initially a direct focus of the course, students were eager to discuss the matter, and one of the weekly topics was shifted to discuss surveillance, policing, and ICE in libraries. Discussions of race and racism were central to these class sessions and sessions on many other topics, and because the students were invested in antiracism, there was not a centering of white guilt or white experiences, as can sometimes occur in such conversations (Kishimoto, 2018). This shift in focus is like librarians using national and local events related to social justice as research topics to implement critical information literacy (Tewell, 2018). Critical information literacy insists that information literacy is not an inflexible set of skills divorced from context; responding to current events demonstrates a "pedagogy of kairos" that embraces "flexibility and sensitivity to the particular context in which instruction takes place" (Drabinski, 2014, p. 484).

\section{Critical Information Literacy in the Course}

The topics students addressed in class indicated their growing understanding of critical information literacy. For example, in the discussion of race in library and archive collections, students addressed the limitations of cataloging and described how librarians can simultaneously work with patrons within the structures of the catalog and also critique those structures that make the catalog limited in its representation of race and other historically marginalized groups. Weekly discussions often addressed the myth of neutrality in libraries and how to work with patrons to navigate ideological structures that assign objectivity to information from sources that uphold white supremacy and Western hegemony.

Students were able to exercise critical information literacy skills that encouraged them to look at traditional expectations of authority in academic settings and consider the limitations therein, especially given the subject matter. For example, one student who gave a presentation on disability studies and the experience of disabled patrons and workers in libraries used Tweets and other social media posts from disabled activists. While these are 
not necessarily considered "academic," the student identified that these voices were just as valid, relevant, and powerful as those that have access to more formal publishing methods. Focusing on alternative media sources has been embraced by many librarians who teach critical information literacy (Tewell, 2018) and reflects the critical nature of the "Authority is Constructed and Contextual" frame in the the Association of College and Research Libraries (2015) Framework for Information Literacy for Higher Education (Drabinski, 2017). Writing assignments in the course reflected critical information literacy, requiring students to navigate and think critically about authority, information privilege, and expectations of academic discourse. The writing assignments were as follows:

- Essay 1 - students explored how one critical theory intersects with librarianship through a literature review.

- Case study - students examined how a library, archive, or museum provided more inclusive services from a critical lens.

- Essay 2 - students reflected on what critical librarianship meant for their area of interest in libraries, archives, and museums.

- Self-assessment - students described what they learned from completing each major assignment and evaluated their overall performance, considering any feedback received.

For the first essay, we established source requirements together. Students recognized that to be able to discuss how theory applied, they would need at least five sources on that theory specifically, and then would need additional sources "related to how [the] theory [is] being implemented in information services (case studies, news articles, research articles).” In their assignments, students showed how less scholarly sources can provide a richer picture of the concrete application of theory. For the case study, we discussed the importance of their original research, like interviews or observations, to understand and analyze the service more fully. Students recognized that, because of the course and their information privilege, their understanding of inclusive services did not always align with the goals of the service they were examining and highlighted tensions between academic theory and library practice. This tension was often discussed in class and became an important piece of the final assignment where students considered how the course content would interact with

\section{[INNOVATIVE PRACTICES ]}

Rapchak

Introducing Critical Librarianship to Information Professionals 
social, political, and cultural expectations in their libraries. Students had to consider how they would navigate issues like expectations of neutrality, resistant patrons, and hostile coworkers or supervisors in their approach to critical librarianship.

\section{Self-Grading in the Course}

Students graded their assignments for the course in a final assignment. While I gave feedback on each assignment in the form of questions about their thought processes, identification of what they addressed well, and suggestions for areas for expansion or clarification, I did not give a letter or percentage grade. Self-grading allowed students to reflect on what they learned and accomplished throughout the course. It also enabled a dialogue between the student and myself because I was able to give feedback on their own self-assessment. I explained in the syllabus and in the class discussions that I reserved the right to change grades, but the self-assessment assignment meant students were examining their own learning, effort, and growth. I shared with students if I thought the assessment was fair; while most student self-grading scores were accepted, in several cases, the student had graded themselves harshly, and so I was able to begin a conversation with them on why I believed the grade should be higher. Prior research indicates that student self-grading in higher education environments, including in courses taught by librarians, correlates with the grades that professors would assign as well (Lopez-Pastor et al., 2012; Regan et al., 2020). As Jesse Stommel (2018) wrote, going through this process of self-grading means that "the need for objectivity or accuracy gives way to a dialogue-one that is necessarily emergent and subjective" (How I Don't Grade section, para. 7). The self-grading assignment does not try to obfuscate the subjective nature of grading, but instead calls into question the assumption that grading is objective.

Instead of using an instructor-created rubric, as a class we created expectations for the assignments, like the number of sources required, the tone, and indicators of quality, such as thoroughly explaining and supporting ideas. In the self-grading assignment, students reflected on how well they were able to explore and convey their ideas, often evaluating how time limitations, external stressors, and conflicting deadlines limited their ability to meet their own expectations of themselves. Ultimately, though, students described how much new information they were exposed to, processing, and understanding better; how much more they wanted to learn; and how they hoped to apply this knowledge in the future. These responses highlight the type of learning and metacognitive reflection that we hope to see from students when we take a critical information literacy approach-that they are 
reflecting on their thinking processes and the relevance of new information to their lives. The quality of their writing and discussions showed how seriously students took the course, and I would have given high marks to nearly every student were I grading because of the thoughtfulness and thoroughness of their work.

Bringing Our Authentic Selves to the Course

To implement self-grading, trust must be established in the classroom. In an anonymous survey at the midpoint of the term, a student shared that while they had some trepidation about self-grading, they trusted me. Inspired by feminist pedagogy scholars, like bell hooks (1994) and Carolyn Shrewsbury (1987), who critique the power structures, epistemological assumptions, and competition of traditional classrooms, I created trust through bringing my authentic self to the classroom, breaking down hierarchies between student and instructor as much as possible, and empowering students to direct their own learning. Because this course occurred during COVID-19, I provided space and time for students to share their concerns and challenges in their daily lives. As Arellano Douglas (2020) described, in talking with our students and identifying what they need, we can practice an assessment of care that shows we value our relationship with our students, as well as their well-being. Many of the students were or had been working and shared the difficulties created in their work environments during a pandemic. I shared my own concerns and challenges with teaching in an entirely remote environment because, as bell hooks (1994) wrote, "Professors who expect students to share confessional narratives but who are themselves unwilling to share are exercising power in a manner that could be coercive” (p. 21). I did not want my students to feel I was making requests for them to share their affective livelihoods without sharing my own.

The students and I made space to talk about the limitations of the course, including the danger of the course being performative rather than transformative. The assignments and presentations emphasized praxis to counter this possible pitfall. Students focused on realworld examples of the ways in which critical librarianship can inform both our evaluation of current library systems and in future approaches to librarianship in various library types. Students also gave specific examples of how the concepts discussed in the course were informing their interactions and decisions at the libraries in which they worked. 


\section{Student Response to the Course}

Student response to the course was very enthusiastic, both because of the content covered and because of the structure of the course. Students noted that the concepts covered benefitted their thinking on their library praxis. In the anonymous final evaluation of the course, which did not require IRB review according to the Pitt IRB, one student shared:

Out of all the classes I've taken so far in this program, this was the most thought provoking and meaningful class. I can confidently say that there are many things that I have learned through this class that I will carry with me into my professional work.

Another wrote:

This was the best class I have taken in pursuit of my MLIS degree. It helped me frame my thinking around library service and recognize gaps in my own thinking and in the services we aim to provide as librarians. Critical librarianship ties so many of my professional beliefs to my own core values and this class has given me a framework for praxis that I would not have developed if I hadn't taken it.

Allowing students to think through their own experiences in libraries and how these intersect with the critical theories explored in the course meant they began to consider application and how to address issues within the profession from an informed, thoughtful, empathetic, and antiracist position.

Students mentioned benefitting from the critical information literacy aspects of the assignments and what they learned through working through the assignments. One student shared:

The assignments pushed me to fill in some of the gaps I had in my formal disability theory foundation, mainly in that they helped to structure and place my lived experiences and the interpretive disability theory concepts I've picked up from disability advocates in the past few years.

This student highlighted how the assignments, through the integration of research and experience, provided relevant intellectual exploration for them. Another student wrote, "Assignments were very challenging but very applicable to the subject matter, and so the challenge of the assignment was a benefit to my understanding of the subject." While some 
professors may worry that a self-graded course would result in students making less of an effort in the class, the student performance and reaction to the course show students focused on the outcomes of the assignments rather than the grades assigned.

\section{Conclusion}

Because the ideas of critical librarianship can have a profound influence on how we address information literacy, we must open discussions about critical librarianship with LIS students and colleagues. These discussions can inform critical information literacy through the topics that we cover in our classes and sessions and the approaches we take to instruction. Critical information literacy allows us to work with our students to uncover the political and social contexts under which the information lifecycle operates that have not been as thoroughly addressed in information literacy instruction. At Pitt, several of my former students and I have started a critical librarianship reading group; attendees include alums and part-time students who have found that the concepts covered in the course and reading group have influenced the ways in which they navigate their position at their various types of institutions and workplaces.

Those who educate LIS students should consider integrating critical librarianship within their coursework; critical librarianship is relevant to all coursework in LIS (and, indeed, all areas of librarianship) and does not need to be taught in a separate course. Critical librarianship can provide perspectives on medical libraries (Barr-Walker \& Sharifi, 2019), archives (Caswell et al., 20212), academic libraries (Garcia, 2015), public libraries (McElroy, 2017), and more, providing a method of questioning the status quo of standards, organizational systems, and policies surrounding information and services in libraries. Ultimately, it unearths the power structures and hierarchies replicated within our institutions and challenges us-librarians, archivists, and other information professionalsto correct the imbalance and injustice these create.

Many students, regardless of disciplinary background, have experience and understanding of social justice issues that provide different perspectives and insights than those provided by the instructor and course readings. Students in LIS are eager to discuss issues of justice and equity and to critique the status quo, as systems of marginalization and oppression directly impact them, their communities, and their roles as information professionals in their communities (Helkenberg et al., 2018). If we are to address the challenges unearthed by

\section{[INNOVATIVE PRACTICES ]}

Rapchak

Introducing Critical Librarianship to Information Professionals 
critical librarianship and critical information literacy in our classrooms, taking a critical pedagogy approach enables us to work alongside our students to redress the harms perpetuated by our libraries, archives, and museums that have for so long purported to be havens of democracy but have historically excluded the voices and experiences of so many. We owe as much to our communities and our students.

\section{Acknowledgements}

I would like to acknowledge the incredible work of my students, especially the founding members of the Critical Librarianship Reading Group: Anne McLaughlin, Zia Meyer, Derek Nuzum, and Paula Wiley. Their efforts towards social justice in libraries and their communities continue to inspire me.

\section{References}

Adler, M. (2017). Classification along the color line: Excavating racism in the stacks. Journal of critical library and information studies, 1(1), 1-32. https://doi.org/10.24242/jclis.v1i1.17

Arellano Douglas, V. (2020). Moving from critical assessment to assessment as care. Communications in Information Literacy, 14 (1), 46-65. https://doi.org/10.15760/comminfolit.2020.14.1.4

Barr-Walker, J., \& Sharifi, C. (2019). Critical librarianship in health sciences libraries: an introduction. Journal of the Medical Library Association, 107(2), 258-264. https://doi.org/10.5195/jmla.2019.620

Budd, J. M. (2003). The library, praxis, and symbolic power. The Library Quarterly, 73(1), 1932. https://doi.org/10.1086/603373

Caswell, M., Broman, G., Kirmer, J., Martin, L., \& Sowry, N. (2012). Implementing a social justice framework in an introduction to archives course: Lessons from both sides of the classroom. InterActions: UCLA Journal of Education and Information Studies, 8(2). https://escholarship.org/uc/item/2jx083hr

Cooke, N. A., \& Sweeney, M. E. (Eds.). (2017). Teaching for justice: Implementing social justice in the LIS classroom. Library Juice Press.

Cooke, N. A., Sweeney, M. E., \& Noble, S. U. (2016). Social justice as topic and tool: An attempt to transform an LIS curriculum and culture. The Library Quarterly, 86(1), 107124. https://doi.org/10.1086/684147

Rapchak

Introducing Critical Librarianship to

Information Professionals 
Drabinski, E. (2008). Teaching the radical catalog. In K. R. Roberto (Ed.), Radical cataloging: Essays at the front (pp. 198-205). McFarland.

Drabinski, E. (2014). Toward a kairos of library instruction. The Journal of Academic Librarianship, 40(5), 480-485. https://doi.org/10.1016/j.acalib.2014.06.002

Drabinski, E. (2017). A kairos of the critical: Teaching critically in a time of compliance. Communications in Information Literacy, 11(1), 76-94. https://doi.org/10.15760/comminfolit.2017.11.1.35

Elmborg, J. (2012). Critical information literacy: Definitions and challenges. In C. W. Wilkinson, \& C. Bruch, (Eds). Transforming information literacy programs: Intersecting frontiers of self, library culture, and campus community (pp. 75-95). Association of College and Research Libraries.

Forest, D. E., \& Kimmel, S. C. (2016). Critical literacy performances in online literature discussions. Journal of Education for Library and Information Science, 57(4), 283-294. https://doi.org/10.3138/jelis.57.4.283

Freire, P. (2009). Chapter 2 from Pedagogy of the Oppressed. Race/Ethnicity: Multidisciplinary Global Contexts, 2(2), 163-174. (Original work published in 1970)

Galvan, A. (2015). Soliciting performance, hiding bias: Whiteness and librarianship. In the Library with the Lead Pipe. http://www.inthelibrarywiththeleadpipe.org/2015/solicitingperformance-hiding-bias-whiteness-and-librarianship/

Garcia, K. (2015, June). Critical librarianship. Keeping Up With.... http://www.ala.org/acrl/publications/keeping_up_with/critlib

Hackney, S. E., Handel, D., Hezekiah, B., Hochman, J., Lau, A., \& Sula, C. A. (2018). Visualizing identities in LIS literature. Journal of Education for Library and Information Science, 59(1-2), 10-32. https://doi.org/10.3138/jelis.59.1-2.04

Hare, S., \& Evanson, C. (2018). Information privilege outreach for undergraduate students. College \& Research Libraries, 79(6), 726-736. https://doi.org/10.5860/crl.79.6.726

Hathcock, A. (2015). White librarianship in blackface: Diversity initiatives in LIS. In the Library with the Lead Pipe. http://www.inthelibrarywiththeleadpipe.org/2015/lisdiversity 
Helkenberg, D. L., Schoenberger, N., Kooy, S., Pemberton, A., Ali, K., Bartlett, S., Clair, J., Crombleholme, S., Dee, A., DePierro, K., Greenwood, T., Lobzun, M., Petersen, C., Saunders, S.E., Tarzi, M., Ward, K., \& Zip, S. (2018). Education for the common good: A student perspective on including social justice in LIS education. Journal of Education for Library and Information Science, 59(4), 265-272. https://doi.org/10.3138/jelis.59.4.2018$\underline{0013}$

Hochman, J. (2016). Collaborative pedagogies: LIS courses and public library partnerships. In N. Pagowsky \& K. McElroy (Eds.), Critical library pedagogy handbook: Vol. 1 (pp. 101109). Association of College and Research Libraries.

Honma, T. (2005). Trippin'over the color line: The invisibility of race in library and information studies. InterActions: UCLA Journal of Education and Information Studies, 1(2). https://escholarship.org/uc/item/4nj0w1mp

hooks, b. (1994). Teaching to transgress: Education as the practice of freedom. Routledge.

Hughes-Hassell, S., \& Vance, K. J. (2017). Examining race, power, and privilege in the youth services LIS classroom. In N. A. Cooke \& M.E. Sweeney (Eds.), Teaching for justice: Implementing social justice in the LIS classroom (pp. 103-138). Library Juice Press.

Kendi, I. X. (2019). How to be an antiracist. One World

Kishimoto, K. (2018). Anti-racist pedagogy: From faculty's self-reflection to organizing within and beyond the classroom. Race Ethnicity and Education, 21(4), 540-554. https://doi.org/10.1080/13613324.2016.1248824

Kurz, Robin. (2017). Transgressing LIS education: a continuing journey toward social justice. In N. A. Cooke \& M.E. Sweeney (Eds.), Teaching for justice: Implementing social justice in the LIS classroom (pp. 77-99). Library Juice Press.

Lopez-Pastor, V. M., Fernandez-Balboa, J.-M., Santos Pastor, M. L., \& Aranda, A. F. (2012). Students' self-grading, professor's grading and negotiated final grading at three university programmes: Analysis of reliability and grade difference ranges and tendencies.

Assessment \& Evaluation in Higher Education, 37(4), 453-464.

https://doi.org/10.1080/02602938.2010.545868

McElroy, K. (2017). But how do we do critical librarianship? OLA Quarterly, 23(2), 6-8. https://doi.org/10.7710/1093-7374.1893

Rapchak

Introducing Critical Librarianship to

Information Professionals 
Mehra, B., \& Rioux, K. (2016). Progressive community action: Critical theory and social justice in library and information science. Library Juice Press.

Noble, S. U. (2018). Algorithms of oppression: How search engines reinforce racism. New York University Press.

Pagowsky, N., \& McElroy, K. (Eds.). (2016). Critical Library Pedagogy Handbook. Association of College and Research Libraries.

Pashia, A. (2016). Black Lives Matter in information literacy. Radical Teacher, 106, 141-43. https://doi.org/10.5195/rt.2016.305

Regan, M. T., Young, S. W. H., \& Mannheimer, S. (2020). Improving learner-driven teaching practices through reflective assessment. Evidence Based Library and Information Practice, 15(3), 59-77. https://doi.org/10.18438/eblip29729

Roberts, S. T., \& Noble, S. U. (2016). Empowered to name, inspired to act: Social responsibility and diversity as calls to action in the LIS context. Library Trends, 64(3), 512-532. https://doi.org/10.1353/lib.2016.0008

Shrewsbury, C. M. (1987). What is feminist pedagogy? Women's Studies Quarterly, 15(3/4), 6-14.

Stommel, J. (2018, March 11). How to ungrade. https://www.jessestommel.com/how-toungrade/

Swanson, T. A. (2004). A radical step: Implementing a critical information literacy model. portal: Libraries and the Academy, 4(2), 259-273. https://doi.org/10.1353/pla.2004.0038

Tewell, E. (2015). A decade of critical information literacy: A review of the literature. Communications in Information Literacy, 9(1), 24-43. https://doi.org/10.15760/comminfolit.2015.9.1.174

Tewell, E. C. (2018). The practice and promise of critical information literacy: Academic librarians' involvement in critical library instruction. College \& Research Libraries, 79(1), 10-34. https://doi.org/10.5860/crl.79.1.10

\section{[INNOVATIVE PRACTICES ]}

Introducing Critical Librarianship to
Information Professionals 